\title{
Hazard Identification and Risk Assessment in the Olive Products Manufacturing Industry
}

\author{
R.Manikandan, S.Rajesh, Chatush, P.Sibhin, Vignesh, G.Rampranav
}

\begin{abstract}
Nowadays health and safety issued have been raised all the manufacturing industry during making products. Here the work is considered about the manufacturing process of Olive products and issues faced by workers in the industry. In industry workers mostly exposed by health and safety hazards. The objective of this study is to identify the risk level in the manufacturing process of Olive in industry and to assessment procedure is given for access to the manufacturing process without adverse effect to the human being. The risk level is estimated using hazards, risk (probability of hazards), severity and risk assessment matrix. Based on the aforementioned consideration in the industry during the manufacturing process of Olive, the risk management action is given and it should be reviewed and documented.
\end{abstract}

Keywords: Health issues, Safety issues, Olive manufacturing process, Risk assessment.

\section{INTRODUCTION}

$\mathrm{T}$ The risk assessment process is a very essential part of managing health and safety and control hazards exist in the industry. The company support to carry out the risk assessment shows its commitment to ensuring a safe and healthy work environment. An accident is unwanted and can occur unexpectedly by making losses. Before an accident, it will show many symptoms like near misses and some deficiencies. We have to observe it and the action should take, because that all are warnings of disaster. It is better to think before an accident occurs than thinking afterward. Risk assessment and identification is an important technique in project risk management and establishes the implication of several risks that are existing in the industry [1]. The objective of a risk assessment is to identify all of the risks that can be associated with a task, activity or process and take the respective control measures in place to reduce the risk level.

Revised Manuscript Received on December 30, 2019.

* corresponding author

Mr. R.Manikandan, Department of Mechanical Engineering, Kalasalingam Academy of Research and Education, Virudhunagar, Tamilnadu. Email: rmanikandan198@gmail.com

Dr.S.Rajesh*, Department of Mechanical Engineering, Kalasalingam Academy of Research and Education, Virudhunagar, Tamilnadu. Email: s.rajesh@klu.ac.in

Chatush, Department of Mechanical Engineering, Kalasalingam Academy of Research and Education, Virudhunagar,. Email chathushvp7@gmail.com

P.Sibhin, Department of Mechanical Engineering, Kalasalingam Academy of Research and Education, Virudhunagar,. Email: sibins29@gmail.com

Vignesh Department of Mechanical Engineering, Kalasalingam Academy of Research and Education, Virudhunagar, Email: vigneshpc98@gmail.com

G.Rampranav M.Tech (ISE), Department of Mechanical Engineering, Kalasalingam Academy of Research and Education, Virudhunagar, Email rampranav0428@gmail.com
The workers are exposed to various health and safety hazards in the construction industry. In the workplace, occupational risk assessment is the best tool to implement adequate safety measures [2]. Develop the methodology of supplier risk assessment to measure, track, and analyze the supplier and part specific risk more than time for an automotive producer [3]. The assessment of risk and risk management plan is given to the chemical processing industry with consideration of health and safety issues happening in the chemical industry [4]. Development of risk assessment methodology for the nuclear power industry with consideration of safety hazards present in the industry [5]. The various steps are involved in risk assessment techniques,

- Define the scope

- Identify the hazards

- Assess the risk

- Decide on control measures.

- Implement the control

- Monitor and review

Analyze the Occupational Safety and Health of the worker who is all working in Olive Oil Mils to improve the quality of risk assessment and current practices for their exposure of health and safety hazards in the industry [6]. The occupational risks, the lack of reliable data [7-9], time available, applied methods quality [10] and the criteria that can be used to support the decisions for acceptance level of risk [11,12] are different key troubles that decide the reliability of risk assessment process. In this study identified the various health and safety possible issues are exposing by the worker during the manufacturing of Olive products and safety recommendations are given based on the risk priority level

\section{METHODOLOGY}

In the olive product manufacturing industry, the various steps to be followed to make products.

- The receiving of olive fruits

- Cleaning and crushing olive fruits

- Malaxation process

- Extraction process

- Olive oil and its products.

In this aforementioned process risk assessment is conducted and identified various hazards involved in manufacturing of olive products in the industry. 
The hazards are identified by visual monitoring and interact with workers, collected the following issues happening in the industry. Health hazards like inhaling dust particles and it leads to the lung disorder. Safety hazards like fire, the possibility of physical injury by working at height. The methods for assessing the risk in this manufacturing process of Olive is based on the following,

- Hazards

- Probability of hazards (Risk)

- Severity

- Risk Assessment matrix

- Finally, risk management action will be given based on the above consideration.

The risk is assessed by following formulae,

- A risk is defined as the likelihood that a hazard will cause harm to the people, property, and environment.

Relative Risk $=$ Likelihood $\times$ Severity

- The hazard severity and its ratings can be listed in the below table. Severity defines the degree of harm that can be fashioned by the event. The likelihood is the Probability of occurrence of harm.

The risk Assessment matrix is calculated by using below Table. 1

Table- I: Risk Assessment Matrix Severity

\begin{tabular}{|c|c|c|c|c|c|}
\hline & $\begin{array}{c}\text { Insignificant } \\
1\end{array}$ & $\begin{array}{l}\text { Minor } \\
2\end{array}$ & $\begin{array}{c}\text { Moderate } \\
3\end{array}$ & $\begin{array}{c}\text { Major } \\
4\end{array}$ & $\begin{array}{c}\text { Catastrophe } \\
5\end{array}$ \\
\hline $\begin{array}{c}\text { Almost certain } \\
5\end{array}$ & $\begin{array}{c}\text { Medium } \\
5\end{array}$ & $\begin{array}{c}\text { High } \\
10\end{array}$ & $\begin{array}{c}\text { High } \\
15\end{array}$ & $\begin{array}{c}\text { Extrem e } \\
20\end{array}$ & $\begin{array}{c}\text { Extrem e } \\
25\end{array}$ \\
\hline $\begin{array}{c}\text { Likely } \\
4\end{array}$ & $\begin{array}{c}\text { Medium } \\
4\end{array}$ & $\begin{array}{c}\text { Medium } \\
8\end{array}$ & $\begin{array}{c}\text { High } \\
12\end{array}$ & $\begin{array}{c}\text { High } \\
16\end{array}$ & $\begin{array}{l}\text { Extrem e } \\
20\end{array}$ \\
\hline $\begin{array}{c}\text { Possible } \\
3\end{array}$ & $\begin{array}{c}\text { Low } \\
3\end{array}$ & $\begin{array}{c}\text { Medium } \\
6\end{array}$ & $\begin{array}{l}\text { Medium } \\
9\end{array}$ & $\begin{array}{c}\text { High } \\
12\end{array}$ & $\begin{array}{l}\text { High } \\
15\end{array}$ \\
\hline $\begin{array}{c}\text { Unlikely } \\
2\end{array}$ & $\begin{array}{c}\text { Low } \\
2\end{array}$ & $\begin{array}{c}\text { Medium } \\
4\end{array}$ & $\begin{array}{l}\text { Medium } \\
6\end{array}$ & $\begin{array}{c}\text { Medium } \\
8\end{array}$ & $\begin{array}{c}\text { High } \\
10\end{array}$ \\
\hline $\begin{array}{c}\text { Rare } \\
1\end{array}$ & $\begin{array}{c}\text { Low } \\
1\end{array}$ & $\begin{array}{c}\text { Low } \\
2\end{array}$ & $\begin{array}{c}\text { Low } \\
3\end{array}$ & $\begin{array}{c}\text { Medium } \\
4\end{array}$ & $\begin{array}{c}\text { Medium } \\
6\end{array}$ \\
\hline
\end{tabular}

In the manufacturing industry, the risk definitely comes under an almost certain and likely category. The severity depends on the level of risk based on their nature of work .involved. The risk level rating and its criteria are given Table. 2

Table- II: Level of Risk Rating and its criteria

\begin{tabular}{|c|c|}
\hline Rating & Criteria \\
\hline Insignificant & $\begin{array}{l}\text { 1. Minor injury } \\
\text { 2. No basic firs a ridrequired } \\
\text { 3. Loss of work efficiency } \\
\text { 4. Productionloss }\end{array}$ \\
\hline Minor & $\begin{array}{l}\text { 1. Medical and par am edical treatm ent } \\
\text { 2. Loss of work time. } \\
\text { 3. Near misses } \\
\text { 4. Workers dissatifaction }\end{array}$ \\
\hline
\end{tabular}

The risk assessment was conducted in various location of the Olive manufacturing process and identified some health and safety issues are faced by the worker during the manufacturing process of olive products. The detailed risk assessment model report is given Table.3. 
Table- III: Risk Assessment: Data Collection and Evaluation

\begin{tabular}{|c|c|c|c|c|c|c|c|c|c|}
\hline Title & \multicolumn{9}{|c|}{ Risk assessment-Olive life sciences Pvt. Ltd. } \\
\hline Location & \multicolumn{9}{|c|}{ Solvent Yard } \\
\hline \multirow{2}{*}{$\begin{array}{l}\text { Type of } \\
\text { hazards }\end{array}$} & \multirow{2}{*}{ Reason } & \multirow{2}{*}{$\begin{array}{c}\text { Consequence } \\
\mathrm{s}\end{array}$} & \multicolumn{3}{|c|}{ Level of risk } & \multirow{2}{*}{ Control measures } & \multicolumn{3}{|c|}{ Residual risk } \\
\hline & & & Severity & $\begin{array}{c}\text { Likelihoo } \\
d\end{array}$ & $\begin{array}{c}\text { Risk } \\
\text { rating }\end{array}$ & & Severity & Likelihood & $\begin{array}{c}\text { Risk } \\
\text { rating }\end{array}$ \\
\hline \multirow[t]{2}{*}{$\begin{array}{l}\text { Solvent } \\
\text { Leakage }\end{array}$} & $\begin{array}{l}\text { The main hose } \\
\text { is damaged or } \\
\text { loosely fitted } \\
\text { into the tanker } \\
\text { valve end. }\end{array}$ & Fire & $\begin{array}{c}\text { Catastrophi } \\
\text { c }\end{array}$ & Unlikely & High & $\begin{array}{l}\text { The connecting } \\
\text { hose for takeout the } \\
\text { solvent from } \\
\text { solvent tanker } \\
\text { should be damage } \\
\text { free and should } \\
\text { properly fix in the } \\
\text { hose thread. } \\
\text { Fire protection } \\
\text { system }\end{array}$ & Major & Rare & Medium \\
\hline & $\begin{array}{l}\text { Crack in the } \\
\text { welded joint of } \\
\text { solvent } \\
\text { transmission } \\
\text { of pipeline }\end{array}$ & Fire & Major & Rare & Medium & $\begin{array}{l}\text { Repair of } \\
\text { pipeline } \\
\text { Inspection } \\
\text { Fire protection } \\
\text { system }\end{array}$ & Moderate & Rare & Low \\
\hline
\end{tabular}

Similarly

- Height work due to climbing over the solvent storage tank during filling for earth rod dipping, hose holding, and liquid level measuring. The level of risk is high.

- Hazards during dried leaves in the storage yard, the fire may occur due to lack of regular cleaning inside the storage yard. The risk level present in this process is moderate.

- Unawareness of worker the accident has occurred in the industry and it's due to the inadequate precautionary sign and labeled warning. The level of risk is moderate.

- Unable to maintain the storage tank, the accident has occurred and it is due to lack of safety devices to support the confined space entry. The level of risk is moderate.

- Similarly, spark (Ignition Source) hazard, the volatility of the solvent increased the hazard, dispersion of vented vapor at the low lying level and insufficiency in bonding and grounding accident may occur.

\section{CONCLUSION}

This risk assessment evident that in work, the place needs to improve and the industry peoples have not following safety practices properly. The identified hazards are controllable with proper risk management and safety practices. The residual risk rating after control recommendations is not contained any 'High' and 'Extreme' rating. The feasible control measures are applied according to the priority with the guidance of management. Most of the accidents and incidents are be avoidable with necessary precautions. The safety control measures must be reviewed and documented.

\section{REFERENCES}

1. S.M, El-Sayegh ,"Risk assessment and allocation in the UAE

2. construction industry,". International journal of project management, 26(4),2008, pp. 431-438.

3. A.Pinto, I.L.Nunes, \& R.A. Ribeiro," Occupational risk

4. assessment in the construction industry Overview and reflection," Safety science, 49(5), 2011, pp. 616-624.

5. J.V.Blackhurst, K.P.Scheibe, \& D.J.Johnson, "Supplier

6. risk assessment and monitoring for the automotive industry," International Journal of Physical Distribution \& Logistics Management, 38(2), 2008, pp. 143-165.

7. Greenberg, H. R., \& Cramer, J. J. (Eds.). (1991). Risk assessment and

8. risk management for the chemicv al process industry. John Wiley \& Sons.

9. R.R.Fullwood, \& R.E.Hall, "Probabilistic risk assessment in

10. the nuclear power industry,"1988.

11. A.Matilde, "Occupational risk assessment at Olive Oil

12. Mills:Limitations and new perspectives," 2016.

13. C.Jacinto, and C.Silva, "A semi-quantitative assessment of

14. occupational risks using bow-tie representation. Safety Science," 48(8),2010, pp. 973-979.

15. A.Pinto, R.A.Ribeiro, and I.L.Nunes," Fuzzy approach for reducing

16. subjectivity in estimating occupational accident severity," Accident Analysis \& Prevention, 45, 2012, pp. 281-290.

17. J.A.Carrillo-Castrillo, J.C.Rubio-Romero, J.Guadix, and L.Onievac,

18. "Risk assessment of maintenance operations: The analysis of performing task and accident mechanism,"International Journal of Injury Control and Safety Promotion, 22(3), 2015, pp. 267-77.

19. V.V.Khanzode, J.Maiti, and P.K.Ray, "Occupational injury and

20. accident research: A comprehensive review," Safety Science, 50(5), 2012, pp. 1355-1367.

21. M.A.Rodrigues, P.M.Arezes and C.P.Leão, "Risk decision in

22. occupational environments: The Portuguese reality," Proceedings of 11th International Probabilistic Safety Assessment and Management Conference and the Annual European Safety and Reliability Conference PSAM11 ESREL 2,2012, pp. 1366-1375.

23. M.A.Rodrigues, P.Arezes and C.P.Leão,” Defining risk acceptance

24. criteria in occupational settings: A case study in the furniture industrial sector," Safety Science, 80,2015, pp. $288-295$ 


\section{AUTHORS PROFILE}

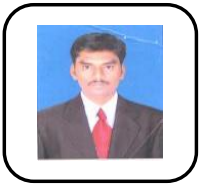

R.Manikandan obtained his B.E (MECH) in 2009 from the P.S.R Engineering College, Sivakasi, Tamilnadu, India. He completed his M.Tech (Industrial Safety Engineering) in 2014 at Mepco Schlenk Engineering College, Tamilnadu, India. Currently, he is working as a Assistant Professor in the Department of Mechanical Engineering, Kalasalingam Academy of Research and Education, Krishnankoil, Tamilnadu, India. His research interests include investigation of fireworks accidents and exposure of various experimental setup like frition, impact sensivity test, Noise level test and thermal analysis test.

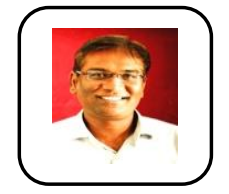

I have completed in B. E in Mechanical Engineering and M.E. (CAD) from Alagappa Chettiar Government College of Engineering and Technology, Karaikudi, Ph.D(Machining of Metal of Matrix Composites) from Kalasalingam Academy of Research and Education, Krishnankoil in the year 2014, and thesis highly recommended by both the examiners. In the year 2018, I have received DST - AMT project for the worth of Rs 25, 72, 400 and completed one IEDC project for the worth of Rs $1,00,000$. I have published more than 25 journal papers (impact factor and Scopus cited) and more than 40 international conference papers.

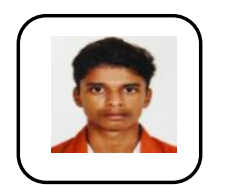

Chatush is a final year student of Mechanical Engineering Department, Kalasalingam Academy of Research and Education, Krishnankoil, Tamilnadu, India

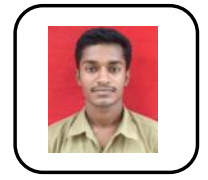

S.Shibin is a final year student, Department of Mechanical Engineering, Kalasalingam Academy of Research and Education, Krishnankoil, Tamilnadu, India.

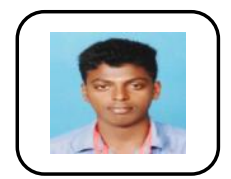

P.C.Vignesh is a final year student, Department of Mechanical Engineering, Kalasalingam Academy of Research and Education, Krishnankoil, Tamilnadu, India.

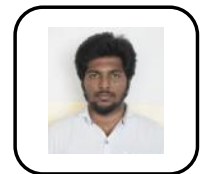

G.Rampranav is a second year M.Tech Industrial Safety Engineering student, Department of Mechanical Engineering, Kalasalingam Academy of Research and Education, Krishnankoil, Tamilnadu, India. 